\title{
Towards Sustainability: An Experimental and Analytical Investigation of an Agricultural Waste as a Pozzolanic Material in Concrete Mixtures
}

\author{
Solomon Melaku Belay (iD) and Asregedew Woldesenbet \\ Faculty of Civil and Water Resource Engineering, Bahir Dar Institute of Technology, Bahir Dar, Ethiopia \\ Correspondence should be addressed to Solomon Melaku Belay; solomon.melaku@bdu.edu.et
}

Received 21 July 2021; Revised 27 November 2021; Accepted 29 January 2022; Published 4 March 2022

Academic Editor: Abdulkadir Cuneyt Aydın

Copyright (c) 2022 Solomon Melaku Belay and Asregedew Woldesenbet. This is an open access article distributed under the Creative Commons Attribution License, which permits unrestricted use, distribution, and reproduction in any medium, provided the original work is properly cited.

\begin{abstract}
The aim of the current study was to explore the potential use of Ethiopian rice husk ash in concrete properties using various replacement levels. A detailed laboratory investigation was conducted to evaluate the chemical, physical, and mechanical properties of normal grade concrete specimens with the addition of finely grounded rice husk ash collected from Fogera Area, Ethiopia. Consequently, a total of 96 concrete cube specimens were molded in varying degrees of proportions of ground risk husk ash including $5 \%, 10 \%, 15 \%$, and $20 \%$ replacement levels and 12 cube specimens with the addition of superplasticizing admixture. All concrete specimens were cured in a laboratory setting, and compressive strength results were recorded at 3, 7, 28, and 56 curing days. The findings reveal that the Ethiopian rice husk ash is suitable for $5 \%$ to $15 \%$ replacement levels. However, the slump flow and density of specimens' tests show that the results have decreased with an increase in rice husk ash level of replacement. Further, the laboratory test results were then validated using a two-way factorial analysis of variance (ANOVA) and post hoc tests.
\end{abstract}

\section{Introduction}

Recently, numerous agricultural wastes are added to cement as a pozzolanic material to enhance the overall properties of concrete and reduce the increasing consumption and cost of Portland cement [1-4]. The most commonly applied pozzolanic materials in various concrete mixes include fly ash, ground granulated blast-furnace slag, silica fume, and natural pozzolanic materials coming from agricultural wastes [5-8]. Supplementary cementitious materials, when partially incorporated with Portland cement, contribute to the fresh and hardened properties of concrete mixes through pozzolanic activity. Prior studies suggest that these supplementary cementitious materials, also known as SCMs, enhancing the quality of concrete mixes by improving slump flow and consistency, increase compressive strength at later curing ages, reducing bleeding, segregation, and heat of hydration, retarding the setting time for hot weather concreting, improving finishing and pumping capability, and reducing plastic shrinkage cracking $[4,9-12]$.

In the past decade, the construction industry was booming in different developing countries including Ethiopia. The main reason is that the Ethiopian government, together with various key stakeholders, has been skeptical to improve the overall growth of the construction sector as part of the growth and transformation plan through various policies and initiatives [13-15]. This growth also draws various international companies to invest in Ethiopia [16]. However, the high price of construction materials, especially cement, is considered to be one of the major challenges that hinders the successful delivery of infrastructures across the nation. Hence, it is vital to find different alternative cement replacements to tackle this problem. One way of addressing this high cost of cement is by utilizing locally available agricultural wastes such as rice husk [13]. 
Prior studies have shown that rice husk ash (RHA) has a potential to replace cement between 10 and $30 \%$ by weight, enhancing compressive strength, chloride ion resistance, and alkali silica reactivity [17-22]. Nevertheless, the production and quality of RHA depend on various factors such as fineness, geographic location, crop year, burning condition, temperature, heating rate, and duration. RHA can typically have two types of states, amorphous or crystalline state [23-28]. These states differ in the extent of burning temperature where amorphous form is found at a temperature between $300^{\circ} \mathrm{C}$ and $900^{\circ} \mathrm{C}$, while burning RHA beyond $1000^{\circ} \mathrm{C}$ produces crystalline silica $[29,30]$. A study by Kulkarni et al. [22] identified that RHA in amorphous state is highly reactive and good for use in concrete.

In addition to its high cost, the production of cement has serious environmental and economic impacts compared to other concrete ingredients [29]. The most significant environmental factors are the consumption of limited natural resources and $\mathrm{CO} 2$ emissions [31-33]. Previously, different researchers have highlighted the application of these natural pozzolans to reduce the environmental impact of cement production $[4,8,34]$.

These findings stressed the introduction of cement replacing materials which have an overall lower cost of production, lower $\mathrm{CO} 2$ emission, and reduced energy consumption to produce a more environmentally, friendly, and green concrete [8]. RHA is one of those cement replacing materials [27]. As it is an agricultural residue, the portion of Portland cement replaced with RHA can greatly reduce the environmental hazards to the ecosystem [35-37]. Thus, this study for the first time investigates the properties of Ethiopian RHA to address the increasing cement cost through the introduction of an alternative pozzolanic material in concrete production of the Ethiopian construction sector. Prior studies reveal that the properties of RHA are greatly affected by the type of species, burning temperature, and duration [38, 39]. In this context, this study explored and examined the Ethiopian RHA through a laboratory led experiment including a superplasticizing additive to compare the impact of the addition of the admixture in the concrete mixture. Further, this paper explored the validation of laboratory test results through a statistical analysis.

\section{Experimental Program}

The aim of the current study is to evaluate the suitability of using Ethiopian RHA as a pozzolanic material in normal grade concrete mixtures. The study mainly focuses on exploring the fresh concrete property such as workability and hardened concrete properties including density and compressive strength of concrete cube specimens made with various RHA replacement levels. Further, statistical analysis was conducted to validate the laboratory test results and draw a reliable conclusion.

Consequently, eight major phases were incorporated as part of the experimental program. These phases are literature review, ingredient selection, sample preparation, chemical test, mix proportioning, concrete cube specimen tests, statistical analysis, and conclusion. These 8 tasks are categorized into 3 phases (Figure 1).

The first stage summarizes prior studies made using RHA as a partial cement replacement, cement hydration in relation to pozzolans and pozzolanic reaction, the importance of RHA in concrete and other sectors, and the different properties and forms of RHA through an extensive literature review and selection of different materials used for the study, which helps to identify the burning temperature of RHA and in the selection of concrete ingredients. The second stage focuses on the experimental work done on the collected ingredients of concrete, coarse aggregate, fine aggregate, and rice husk, chemical analysis test of the RHA, mix proportioning of the materials, and concrete mixing with different RHA proportions; from this, the materials used for concrete casting are identified and oxide composition test of RHA is performed. The third stage incorporates the recording and analysis of test results obtained from the experiment, statistical analysis of the results, cost comparison, and conclusions given based on the abovementioned analysis and the recommendations outlined for future work.

2.1. Material Properties. This section covers the full scope of materials used in the study. The laboratory experiment was conducted using two control mixes made with Ordinary Portland cement (OPC) and Portland Pozzolana cement (PPC), which are both available in the market, and eight other different concrete mixes made with various RHA amounts (four mixes with water reducing admixture and four mixes without water reducing admixture). This is due to the fact that SCMs react slowly after the release of $\mathrm{Ca}(\mathrm{OH})_{2}$ in cement hydration. The early strength development of concrete made with RHA can be assessed well through comparison with concrete made from PPC.

2.1.1. RHA Manufacturing Process. There are two ways of manufacturing RHA: the first one is on a controlled burning environment (which is more preferable) and the uncontrolled one. For this study, the raw rice husk was carefully selected and purchased from one of the largest rice producing regions in Ethiopia, the Fogera area in the Amhara National Regional State (ANRS). The overall stages of the production process, physical and chemical tests of the RHAs, are given as follows.

Production Process. The first stage of the production of RHA is a routine physical examination to check the overall quality of husks. Then, the rice husk was allowed to burn in a laboratory muffle furnace at a temperature of $550^{\circ} \mathrm{C}$ for a total of 6 hours in a controlled burning process inside the furnace before and then cooling for about 24 hours. Finally, the husk is grounded to the required size using ultracentrifugal mill; then the RHA is sieved by $75 \mu \mathrm{m}$ ASTM sieve in order to remove larger size particles before it is used in the concrete mix.

Physical Examination (Test). Once the burning process of the husk is completed, it is turned into whitish-gray color. This whitish-gray color means that the husk is completely 


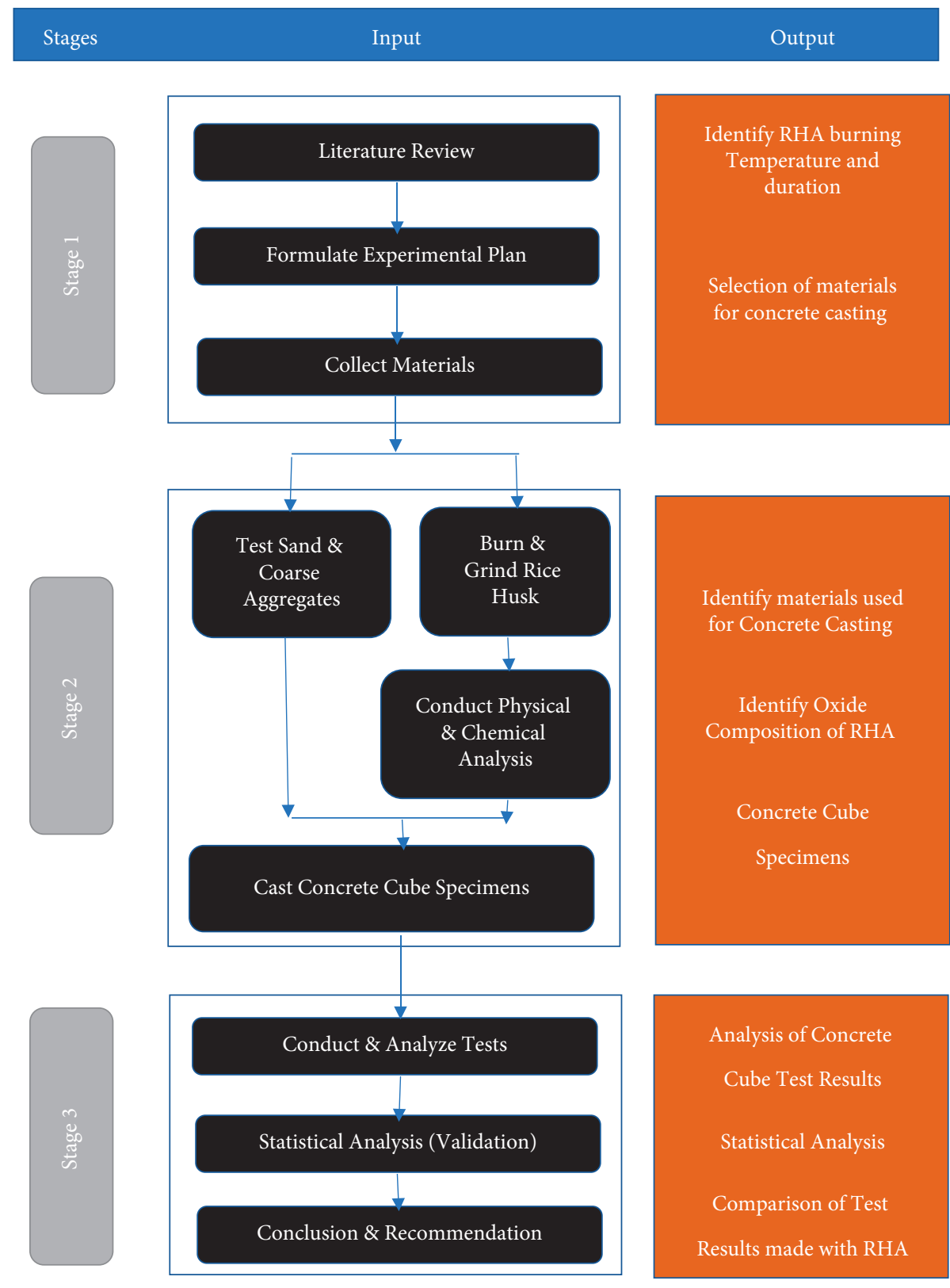

FIGURE 1: Research methodology flowchart.

burned with a lower carbon content. The fact that the rice husk has turned into Gray when grinded proves that the rice husk meets the physical (color) requirement as reported by various researchers. The chemical composition test of the RHA was then conducted at the Ethiopian Geoscience Laboratory. The test result shows that the RHA used in this study also complies with ASTM C618.

Based on Table 1, the sum of the first three major compounds, $\mathrm{SiO}_{2}, \mathrm{Al}_{2} \mathrm{O}_{3}$, and $\mathrm{Fe}_{2} \mathrm{O}_{3}$ is $93.02 \%$, which surpasses the value of 70\%, set by ASTM C618 for pozzolanic materials [40]. The $\mathrm{H}_{2} \mathrm{O}$ content of $2.51 \%$ and $2.85 \%$ of LOI value also complies with the ASTM standard, which sets the maximum value of $3 \%$ and $10 \%$, respectively.
2.1.2. Cement. A total of 108 concrete cube specimens were casted for the study. Consequently, the two most commonly used cement types in Ethiopia, Ordinary Portland cement (OPC) and Portland pozzolana cement (PPC) having grades of $42.5 \mathrm{R}$ and $42.5 \mathrm{~N}$ and manufactured by Messebo Cement Factory, were used in concrete mixtures. The cements were manufactured as per EN 197.

2.1.3. Fine Aggregate. According to ASTM C33, aggregates which are less than $4.75 \mathrm{~mm}$ are designated as fine aggregates (ASTM C 33, 2010). For this study, locally available wellgraded crushed basaltic stones are used as a fine aggregate. 
TABle 1: Chemical composition of Ethiopian RHA used for this study [13].

\begin{tabular}{lccccccccccc}
\hline Chemicals & $\mathrm{SiO}_{2}$ & $\mathrm{Al}_{2} \mathrm{O}_{3}$ & $\mathrm{Fe}_{2} \mathrm{O}_{3}$ & $\mathrm{CaO}$ & $\mathrm{MgO}$ & $\mathrm{Na}_{2} \mathrm{O}$ & $\mathrm{K}_{2} \mathrm{O}$ & $\mathrm{MnO}$ & $\mathrm{P}_{2} \mathrm{O}_{5}$ & $\mathrm{TiO}_{2}$ & Loss on ignition \\
\hline RHA composition (\%) & 92 & 0.66 & 0.36 & 0.01 & 0.01 & 1.02 & 0.01 & 0.08 & 0.42 & 0.07 & 2.85 \\
\hline
\end{tabular}

Figure 2 shows the gradation curve for the fine aggregate used for the investigation with the minimum and maximum limits specified by C33 [41].

Different fine aggregate tests are performed to investigate the quality of the fine aggregate in accordance with ASTM (Table 2).

2.1.4. Coarse Aggregates. According to ASTM C33, aggregates which are larger than $4.75 \mathrm{~mm}$ are designated as coarse aggregates [41].

The gradation curve used in the current study also conforms the ASTM C33 limits (Figure 3).

For this study, locally available well-graded crushed basaltic stones are used, and the summary of test results is shown in Table 3.

2.1.5. Superplasticizer Admixture. For this study, a locally available additive, MegaFlow SP1, was used as a high range water reducing admixture to improve the workability of some of concrete cube specimens.

2.1.6. Samples' Preparation. After the required materials were collected, various tests were performed on each ingredient and compared with the respective ASTM standards to determine their suitability for use in mix proportioning. The samples were designated as control (OPC), control (PPC), RHA5\%, RHA10\%, RHA15\%, RHA20\%, RHAADM5\%, RHAADM 10\%, RHAADM 15\%, and RHAADM $20 \%$.

2.1.7. Chemical Test. Chemical content test is important to determine the mineralogical composition of the RHA. The chemical analysis of the RHA was determined using gravimetrical test and the chemical results are compared with the chemical test requirements set by ASTM [40].

2.1.8. Mix Design and Mixing Procedure. The mix design was performed for C-25 grade nonair entrained concrete as per ACI 211.1. For half of the mixtures, water cement ratio is held constant at 0.49 and, for the rest of the cubes, a water cement ratio of 0.43 and a superplasticizer were used to investigate the workability and compressive strength values of each concrete mix.

For all mixes, a constant amount of $179 \mathrm{~kg} / \mathrm{m}^{3}$ of water, $1120 \mathrm{~kg} / \mathrm{m}^{3}$ of coarse aggregates, and $820 \mathrm{~kg} / \mathrm{m}^{3}$ of sand were used for all mixes. Similarly, $360 \mathrm{~kg} / \mathrm{m}^{3}$ of cement was used for the two control mixes (OPC and PPC); then, 342, 324, 306 , and $288 \mathrm{~kg} / \mathrm{m}^{3}$ of Portland cement were used for 5,10 , 15 , and $20 \%$ RHA replaced concrete mixtures, respectively.

The general procedures of concrete mixing start from materials collection. The collected materials were tested, standardized, and prepared for mixing. The next step was performing mix proportioning for the given grade of normal weight structural concrete and the mixing will follow by controlling all of the factors that affect the overall quality of concrete. At the time of casting, a constant ambient temperature was tried to be maintained. Two control mixes using both Ordinary Portland cement and Portland pozzolanic cement with crushed rock fine and coarse aggregate are proportioned by weight. After that, the OPC was replaced by RHA at $5,10,15$, and $20 \%$. The samples were compacted in three layers and demolded after 24 hours of casting. Finally, the cubes were immersed in water until their test reading was taken. For the test, $15 \times 15 \times 15 \mathrm{~cm}$ of 120 concrete cubes was casted.

2.1.9. Conducting of Tests. Compressive strength of concrete cube specimens is determined after 3, 7, 28, and 56 days of testing using a compressive strength testing machine. All samples were moist cured until the test dates. The reported results are the average of three samples.

2.1.10. Statistical Analysis. Statistical analysis was performed using a two-way factorial analysis of variance (ANOVA) for compressive strength, age of cubes, and RHA replacement levels using a 95\% confidence interval. Post hoc test is also conducted for various RHA replacement levels.

\section{Results and Discussion}

The main objective of this study is to examine the potential applicability of the Ethiopian RHA as a partial replacement of cement in normal weight concrete mixes. Among the most commonly used testing procedures to evaluate the properties of cement based concrete mixtures are workability (to evaluate the ease of concrete flow of fresh concrete properties of concrete) and compressive strength and density tests, to explore the hardened concrete property made with various RHA additions. The following sections provide a brief summary and discussion of the laboratory experiment results.

3.1. Workability. The first test conducted to the freshly mixed concrete made with the addition of RHA in various percentages was workability test. The results reveal that the control concrete cube specimen produced mainly with PPC demonstrated a higher workability value when compared with the remaining the mixtures. It is also important to note that, as the RHA replacement level increases, the value of slump reduced due to the fact that RHA particles had a better fineness and absorption capacity than cement. This is also supported by numerous previous studies in different regions of the world [42-45]. 


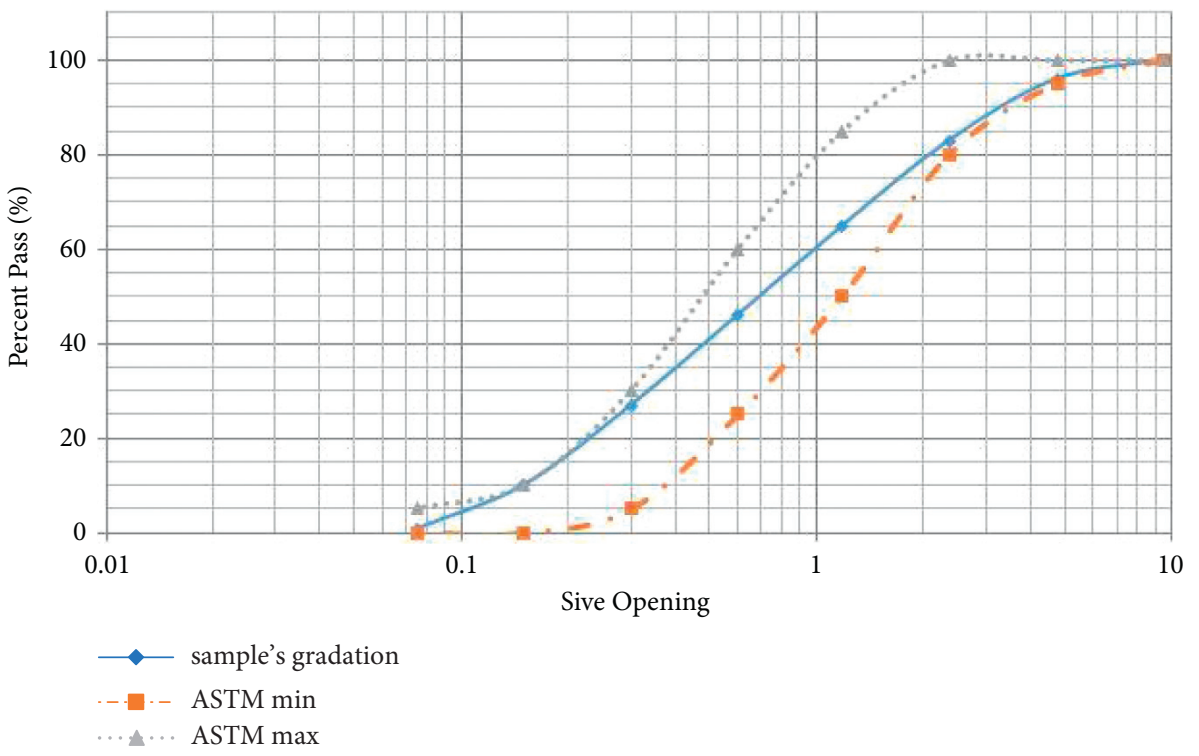

FIGURE 2: Fine aggregate gradation curve with ASTM limits.

TAble 2: Properties of fine aggregate used in this study.

\begin{tabular}{|c|c|c|c|c|}
\hline Characteristics & Test method & Test result & ASTM requirement & Remark \\
\hline Unit weight & ASTM C29 & $1566 \mathrm{~kg} / \mathrm{m} 3$ & 1200 to $1750 \mathrm{~kg} / \mathrm{m}^{3}$ & $\sqrt{ }$ \\
\hline Fineness modulus & ASTM C125 & 2.74 & 2.3 to 3.1 & $\sqrt{ }$ \\
\hline Specific gravity & ASTM C128 & 2.67 & 2.4 to 2.9 & $\sqrt{ }$ \\
\hline Absorption & ASTM C128 & $3.15 \%$ & $0.2 \%$ to $2 \%$ & $\sqrt{ }$ \\
\hline Moisture content & ASTM C566 & $1.6 \%$ & - & $\sqrt{ }$ \\
\hline
\end{tabular}

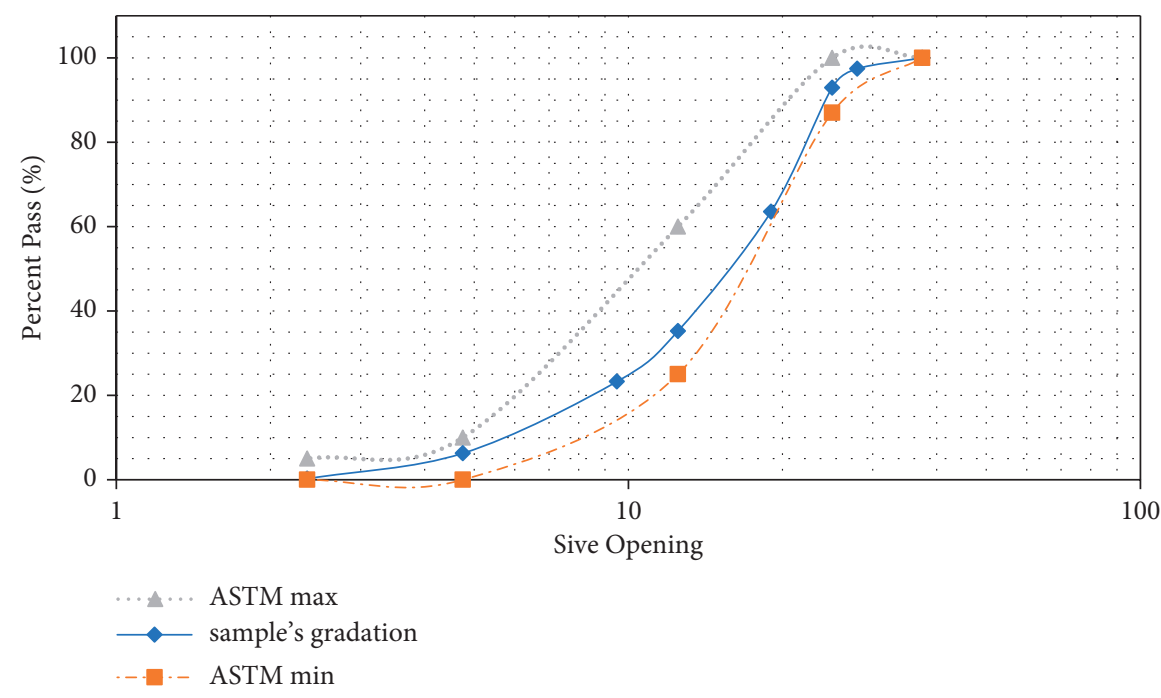

FIGURE 3: Coarse aggregate gradation curve with ASTM limits.

TABLe 3: Properties of coarse aggregate used in this study.

\begin{tabular}{|c|c|c|c|c|}
\hline Characteristics & Test method & Test result & ASTM requirement & Remark \\
\hline Nominal maximum aggregate size & - & $25 \mathrm{~mm}$ & - & $\sqrt{ }$ \\
\hline Unit weight & ASTM C29 & $1653 \mathrm{~kg} / \mathrm{m} 3$ & 1200 to $1750 \mathrm{~kg} / \mathrm{m}^{3}$ & $\sqrt{ }$ \\
\hline Specific gravity & ASTM C127 & 2.8 & 2.4 to 2.9 & $\sqrt{ }$ \\
\hline Absorption & ASTM C127 & $1.89 \%$ & $0.2 \%$ to $4 \%$ & $\sqrt{ }$ \\
\hline Moisture content & ASTM C566 & $0.22 \%$ & - & $\sqrt{ }$ \\
\hline
\end{tabular}


However, for RHA replacement of $15 \%$ and lower values, the findings of slump reveal that the workability is in the required range of 25 to $50 \mathrm{~mm}$, as depicted in the mix proportioning. Accordingly, this decrease in workability of freshly mixed concrete mixes negatively affects the ease of pacing concrete in different structural elements, which in turn affects the quality and performance of concrete at any level [31].

Further, additional 4\% MegaFlow SP1 was used for some of the batches during mixing, in order to improve the workability of the concrete cube specimens and enhance the consistency and ease of placement of the mixes (Table 4). The results reveal that the addition of the superplasticizer increases the workability and made the concrete flow.

\subsection{Compressive Strength}

3.2.1. Early Strength Development. At the $3^{\text {rd }}$ day of curing, control (OPC) and RHA5\% showed a better compressive strength development compared with other mixtures. Similarly, the compressive strength development trend decreased as the RHA replacement percentage increased (Figure 4). Moreover, at the $7^{\text {th }}$ day of curing in the laboratory, the compressive strength test result shows that concrete cube specimens produced with the addition of RHA performed well, as with control (OPC). However, the control (PPC) mixture had a lower compressive strength test result in comparison with all the remaining mix proportions.

In both $3^{\text {rd }}$ and $7^{\text {th }}$ day curing ages, the early compressive strength development of cube specimens decreased as the percentage replacement of RHA increases from $5 \%$ to $20 \%$. The reason is that natural pozzolanic materials hydrate slowly in comparison with the hydration of ordinary Portland cement, provided that curing temperature is maintained in both cases [46].

Concrete cube specimens with admixture:

For both $3^{\text {rd }}$ and $7^{\text {th }}$ days of curing ages, concrete specimens made with the addition of superplasticizer showed a slight decrease in the early compressive strength development trend as the RHA replacement levels increased (Figure 5). However, the workability (slump) of these mixtures improved due to the inclusion of MegaFlow SP1.

3.2.2. Compressive Strength Trend. The overall compressive strength development trend at the $3^{\text {rd }}, 7^{\text {th }}, 28^{\text {th }}$, and $56^{\text {th }}$ curing days including superplasticizer is illustrated in Table 5 .

(A) Concrete without superplasticizer:

Concretes made with the addition of RHA show a good compressive strength development and achieved the target mean strength of $33.5 \mathrm{MPa}$ at 28 days except control (PPC) and 20\% replacement level. Although the control (PPC) and RHA 20\% showed the lowest $28^{\text {th }}$ day result with 28.01 and $31.36 \mathrm{MPa}$, respectively, concrete mixes pass the $25 \mathrm{MPa}$ specified compressive strength at the age of $28^{\text {th }}$ day. Compressive strength at $56^{\text {th }}$ day is found to be higher at $5 \%, 10 \%$, and $15 \%$ replacements than the control OPC mix. However, as the RHA replacement percentage increased, the compressive strength decreases.

It is also shown in Figure 6 that age is an important factor in the compressive strength development of pozzolanic materials. Concretes made within corporation of pozzolanic materials show a good strength development as the curing age increases upto $56^{\text {th }}$ days, where at the $56^{\text {th }}$ day RHA $10 \%$ showed an average compressive strength of $40.21 \mathrm{MPa}$ (the highest compressive strength of concrete mixes).

(B) Concrete with superplasticizer:

In the case of concrete cube specimens made with the addition of superplasticizing admixture, the laboratory testing result revealed an improvement in the overall compressive strength trend at $28^{\text {th }}$ and $56^{\text {th }}$ days. However, at early ages of $3^{\text {rd }}$ and $7^{\text {th }}$ days, the control (OPC) showed a better compressive strength development than the remaining mixes.

As it is illustrated in Figure 7, RHASP $10 \%$ and RHASP $15 \%$ showed a better strength development with an increase in age. These concrete mixes also have a similar trend with the concrete mixes made without admixture.

3.3. Statistical Analysis. This section focuses on the statistical analysis done on the conducted laboratory test results. A statistical software package SPSS ${ }^{\circledR} 23$ was used to perform a two-way factorial analysis of variance (ANOVA) based on the dependent variable (compressive strength) and 2 independent variables (age and RHA replacement level). Statistical approach is used to determine if there is a correlation between compressive strength, age of cubes, and RHA percentage replacement [47].

3.3.1. Two-Way Factorial ANOVA. When dealing with a single experimental data/information, if there are multiple independent variables/cases and a single dependent variable, the method implemented to test the effect of those independent variables on the dependent variable is called twoway factorial ANOVA [48]. When multiple variables are used, each variable will have different levels. Therefore, it is customary to analyze the combination of different levels on each variable.

3.3.2. Hypothesis Testing in Factorial ANOVA. Testing hypothesis helps in finding closure in an experiment based on the formulated hypothesis. Normally, there are two types of hypothesis, null hypothesis and alternative hypothesis [49]. Null hypothesis denoted by " $H_{0}$ " is a hypothesis that is used to disprove or reject a statement, while an alternative hypothesis $\left(H_{a}\right)$ is used to explain the cause of a phenomenon or anticipated relationship of the variables or treatments $[50]$. 
TABLE 4: Workability test results of freshly mixed concrete mixtures.

\begin{tabular}{lcc}
\hline Designation & RHA percentage replacement & \\
\hline Control (OPC) & 0 & $30 \mathrm{~mm}$ \\
Control (PPC) & 0 & $34 \mathrm{~mm}$ \\
RHA 5\% & $5 \%$ & $28 \mathrm{~mm}$ \\
RHA 10\% & $10 \%$ & $25 \mathrm{~mm}$ \\
RHA 15\% & $15 \%$ & $25 \mathrm{~mm}$ \\
RHA 20\% & $20 \%$ & $20 \mathrm{~mm}$ \\
RHAADM 5\% & $5 \%$ & - \\
RHAADM 10\% & $10 \%$ & - \\
RHAADM 15\% & $15 \%$ & - \\
RHAADM 20\% & $20 \%$ & - \\
\hline
\end{tabular}

RHA stands for rice husk ash and RHAADM is rice husk ash with admixture.

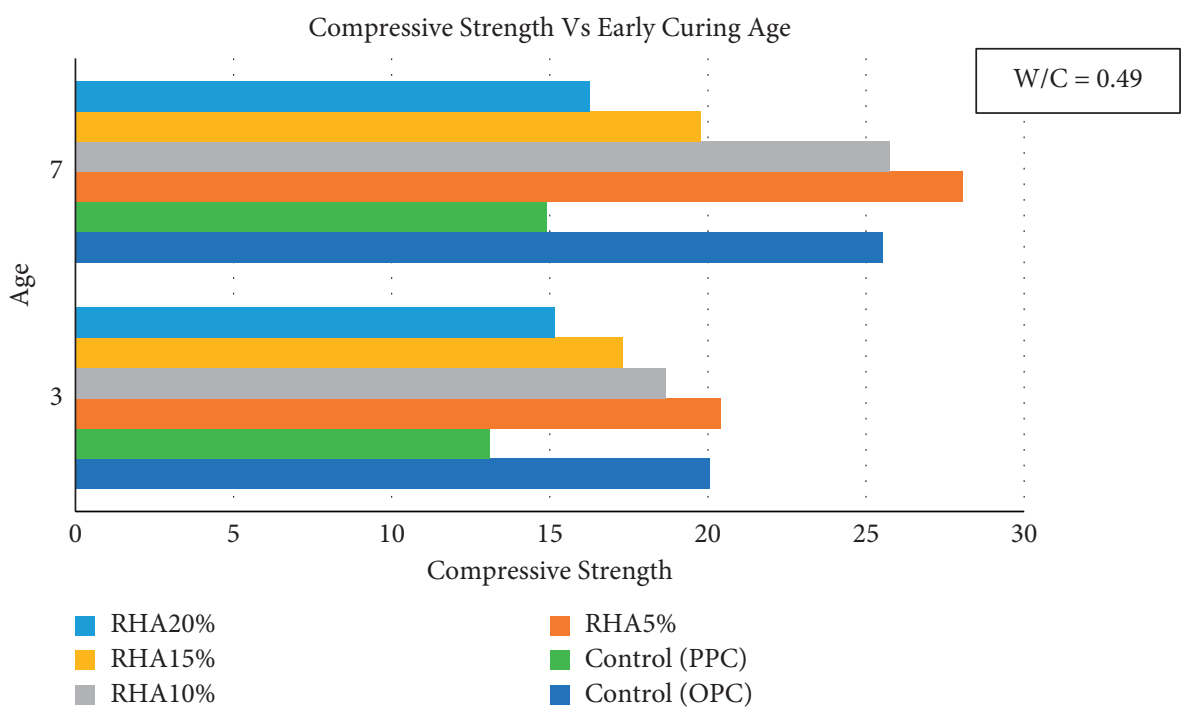

FIgURE 4: Early compressive strength development at $3^{\text {rd }}$ and $7^{\text {th }}$ curing days without superplasticizer.

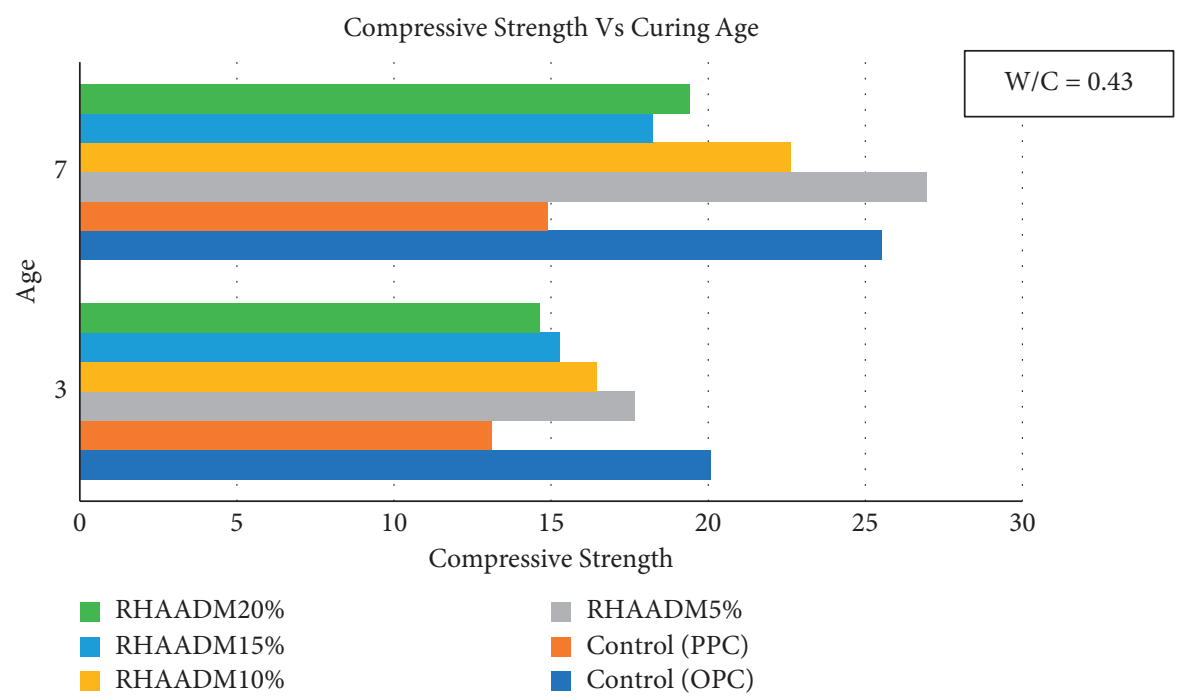

FiguRE 5: Early compressive strength gain at $3^{\text {rd }}$ and $7^{\text {th }}$ curing days with superplasticizer. 
TABLE 5: Average compressive strength results of concrete cubes.

\begin{tabular}{lcccc}
\hline \multirow{2}{*}{ Designation } & \multicolumn{3}{c}{ Average compressive strength results } \\
& $3^{\text {rd }}$ day & $7^{\text {th }}$ day & $28^{\text {th }}$ day & $56^{\text {th }}$ day \\
\hline Control (OPC) & 17.22 & 29.99 & 33.31 & 34.60 \\
Control (PPC) & 11.71 & 24.1 & 28.01 & 30.56 \\
RHA 5\% & 17.3 & 31.76 & 35.76 & 38.16 \\
RHA 10\% & 17.66 & 29.54 & 34.88 & 30.21 \\
RHA 15\% & 14.99 & 28.12 & 33.88 & 36.87 \\
RHA 20\% & 14.26 & 26.38 & 36.36 & 33.55 \\
RHAADM 5\% & 17.26 & 28.86 & 35.80 & 39.01 \\
RHAADM 10\% & 16.44 & 27.34 & 34.91 & 40.30 \\
RHAADM 15\% & 15.28 & 27.30 & 34.08 & 38.52 \\
RHAADM 20\% & 14.64 & 25.55 & 32.21 & 34.87 \\
\hline
\end{tabular}

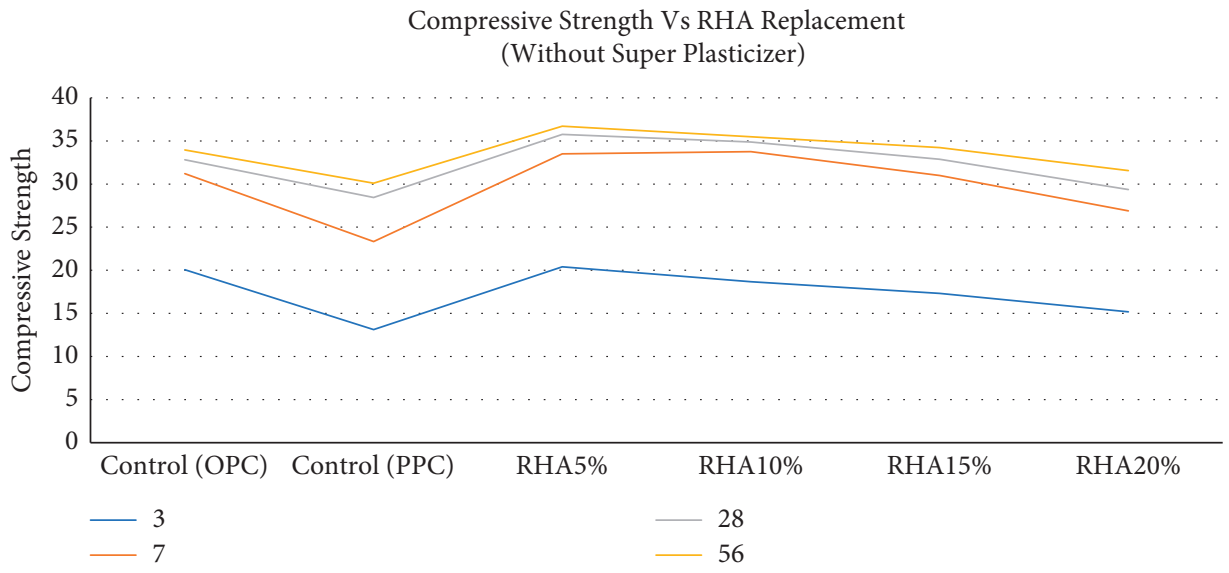

FIGURE 6: Compressive strength vs. RHA replacement for concretes without superplasticizing admixture.

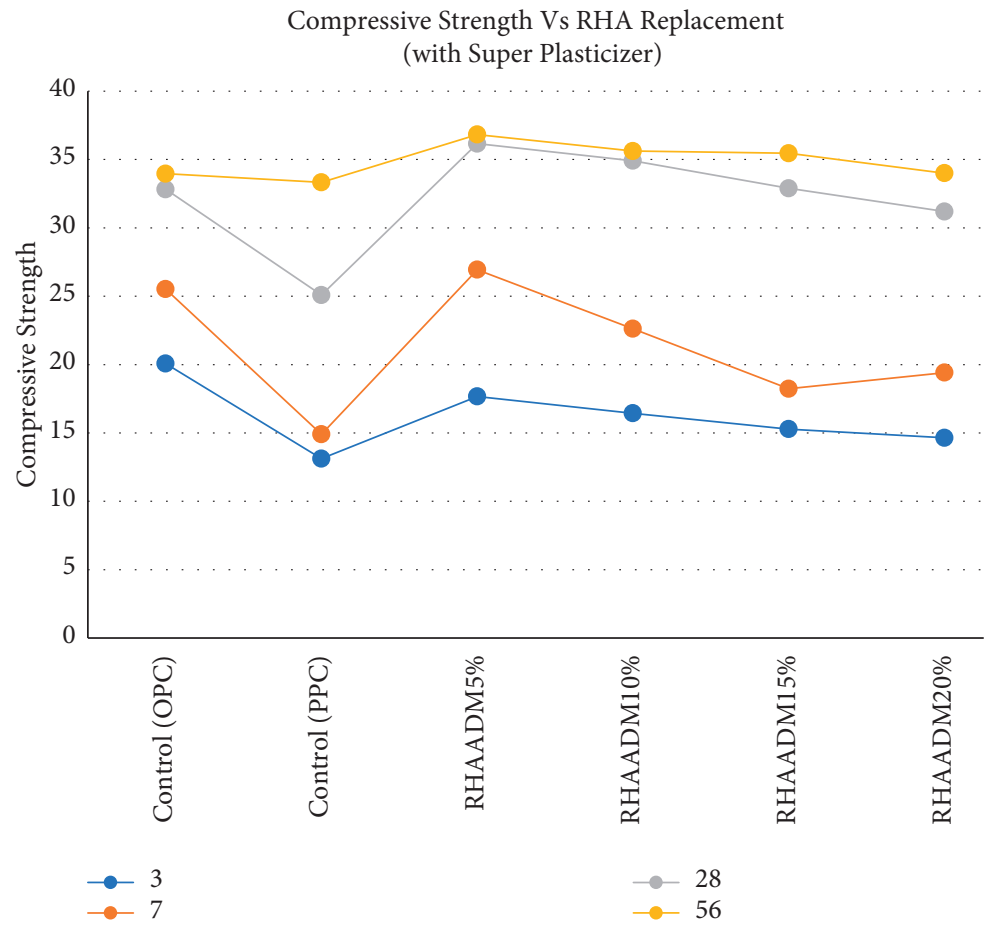

Figure 7: Compressive strength vs. RHA replacement for concretes with the addition of superplasticizing admixture. 


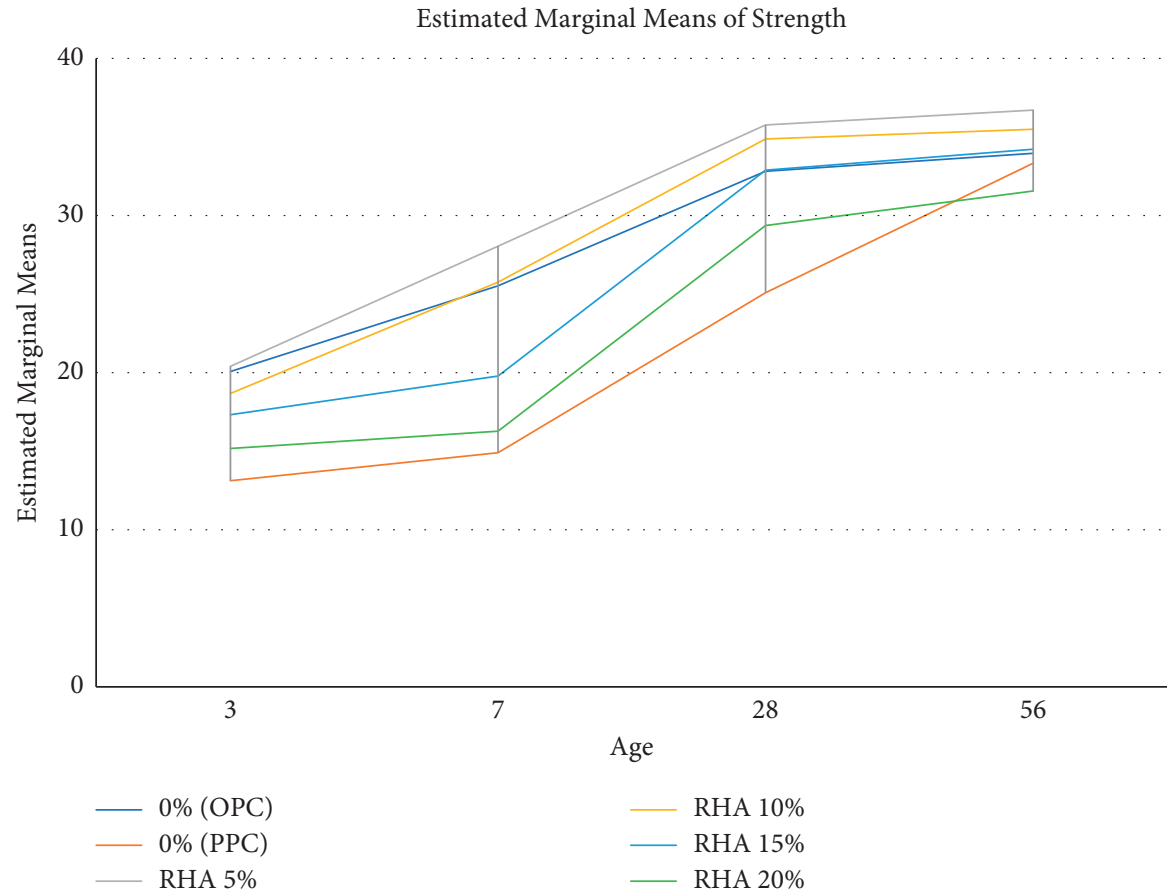

Figure 8: Profile plots for different RHA replacement levels.

TABLE 6: Statistical analysis results of the main effects and interaction effect [52].

\begin{tabular}{|c|c|c|c|c|c|c|}
\hline Sources & Sum of squares & $F$ & DF & Mean square & Pvalue & $P^{*}$ \\
\hline Curing duration & 2735.7 & 330.5 & 3 & 911.9 & $2.98 * E-28$ & 0.96 \\
\hline Rice husk ash & 363.9 & 32.9 & 4 & 90.98 & $3.54 * E-12$ & 0.77 \\
\hline Curing duration $*$ rice husk ash & 93.2 & 2.8 & 12 & 7.8 & $6.94 * 10^{3}$ & 0.46 \\
\hline
\end{tabular}

TABLe 7: Post hoc analysis for RHA replacements.

\begin{tabular}{|c|c|c|c|c|c|c|c|}
\hline & \multirow{2}{*}{ (I) RHA } & \multirow{2}{*}{ (J) RHA } & \multirow{2}{*}{ Mean difference $(\mathrm{I}-\mathrm{J})$} & \multirow{2}{*}{ Std. error } & \multirow{2}{*}{$P$ value } & \multicolumn{2}{|c|}{$95 \%$ confidence interval } \\
\hline & & & & & & Lower bound & Upper bound \\
\hline \multirow{20}{*}{ Tukey's HSD } & \multirow{4}{*}{$0 \%(\mathrm{OPC})$} & RHA $10 \%$ & $-1.7917^{*}$ & .59411 & 0.034 & -3.4885 & -.0948 \\
\hline & & RHA $15 \%$ & .3175 & .59411 & 0.983 & -1.3793 & 2.0143 \\
\hline & & RHA $20 \%$ & $2.3908^{*}$ & .59411 & 0.002 & .6940 & 4.0877 \\
\hline & & RHA 5\% & $-1.9642^{*}$ & .59411 & 0.016 & -3.6610 & -.2673 \\
\hline & \multirow{4}{*}{ RHA $10 \%$} & $0 \%(\mathrm{OPC})$ & $1.7917^{*}$ & .59411 & 0.034 & .0948 & 3.4885 \\
\hline & & RHA $15 \%$ & $2.1092^{*}$ & .59411 & 0.008 & .4123 & 3.8060 \\
\hline & & RHA $20 \%$ & $4.1825^{*}$ & .59411 & $<0.001$ & 2.4857 & 5.8793 \\
\hline & & RHA 5\% & -.1725 & .59411 & 0.998 & -1.8693 & 1.5243 \\
\hline & \multirow{4}{*}{ RHA $15 \%$} & $0 \%(\mathrm{OPC})$ & -.3175 & .59411 & 0.983 & -2.0143 & 1.3793 \\
\hline & & RHA $10 \%$ & $-2.1092^{*}$ & .59411 & 0.008 & -3.8060 & -.4123 \\
\hline & & RHA $20 \%$ & $2.0733^{*}$ & .59411 & 0.010 & .3765 & 3.7702 \\
\hline & & RHA $5 \%$ & $-2.2817^{*}$ & .59411 & 0.004 & -3.9785 & -.5848 \\
\hline & \multirow{4}{*}{ RHA $20 \%$} & $0 \%(\mathrm{OPC})$ & $-2.3908^{*}$ & .59411 & 0.002 & -4.0877 & -.6940 \\
\hline & & RHA $10 \%$ & $-4.1825^{*}$ & .59411 & $<0.001$ & -5.8793 & -2.4857 \\
\hline & & RHA $15 \%$ & $-2.0733^{*}$ & .59411 & 0.010 & -3.7702 & -.3765 \\
\hline & & RHA $5 \%$ & $-4.3550^{*}$ & .59411 & $<0.001$ & -6.0518 & -2.6582 \\
\hline & \multirow{4}{*}{ RHA 5\% } & $0 \%(\mathrm{OPC})$ & $1.9642^{*}$ & .59411 & 0.016 & .2673 & 3.6610 \\
\hline & & RHA $10 \%$ & .1725 & .59411 & 0.998 & -1.5243 & 1.8693 \\
\hline & & RHA $15 \%$ & $2.2817^{*}$ & .59411 & 0.004 & .5848 & 3.9785 \\
\hline & & RHA $20 \%$ & $4.3550^{*}$ & .59411 & $<0.001$ & 2.6582 & 6.0518 \\
\hline
\end{tabular}


The alternative and null hypotheses for two variables can be expressed using the following two statistical notations [50]:

Alternative hypothesis $\mathrm{H}_{\mathrm{a}}: \mu_{a 1} \neq \mu_{a 2}: \mu_{a 1}$ and $\mu_{a 2}$ represent alternative hypothesis

Null hypothesis $\mathrm{H}_{0}: \mu_{01}=\mu_{02}$, where $\mu_{01}$ and $\mu_{02}$ represent the null hypothesis

During the computation of a factorial ANOVA, since there are multiple independent variables, normally various null and alternative hypothesis will be formulated depending on the number of cases considered in study [51]. The impacts of those multiple independent variables can be categorized as main effects and interaction effects. Main effect in this case is considered as the individual effects of RHA replacement and curing age on compressive strength, whereas interaction effect is the simultaneous effects of both RHA replacement and curing age on compressive strength.

For the current investigation, the following hypotheses are formulated:

Null hypothesis (Ho):

$\mu_{01}=$ rice husk ash addition does not have an impact on the concrete compressive strength property

$\mu_{02}=$ curing duration does not have an impact on the concrete compressive strength property

$\mu_{03}=$ the integration of rice husk ash addition and curing duration does not have an impact on the concrete compressive strength property

Significant factors affecting the compressive strength of concrete are as follows.

In this study, two-way factorial ANOVA with a confidence interval of $95 \%$ and a significant level of $\alpha=0.05$ is used to analyze the factors affecting compressive strength of concrete. The decision rule for the conducted F-test on SPSS ${ }^{\circledR}$ for the main effect is the following: if Pvalue $<0.05$, then the variable is considered as a significant factor which affects the compressive strength of concrete, so the null hypothesis is rejected. If $P$ value $\geq 0.05$, the factor is reflected as nonsignificant and the null hypothesis will not be rejected.

After conducting the F-test for main effects, post-hoc test is done to analyze the interaction effect of the variables. The interaction effects consist of four labels for the ages, 3, 7, 28, and 56 days and six labels of RHA replacement, with two control mixes for $0 \%$ and $5 \%, 10 \%, 15 \%$, and $20 \%$ replacement levels for concretes made with and without admixture. The profile plot of different RHA replacements for estimated marginal means of strength at different testing days is illustrated as follows.

Based on Figure 8, the estimated marginal means at the $7^{\text {th }}$ day show a larger difference compared with the other days. RHA 5\% replacement has a better marginal mean upto $56^{\text {th }}$ day and is more significant than the others, while, at the $56^{\text {th }}$ day, RHA $10 \%$ shows an increase in marginal mean.

Based on the profile plot, the strength development of control (OPC) mix is very significant in early days $\left(3^{\text {rd }}\right.$ and $7^{\text {th }}$ day) of concrete mixing; after $7^{\text {th }}$ day, the strength development becomes lower. However, concretes made with
RHA replacement continue their strength development upto $56^{\text {th }}$ days which aliens with the previous studies mentioned in the literature review.

Consequently, as the RHA replacement levels between $5 \%$ and $15 \%$ show a better marginal means for more than $7^{\text {th }}$ strength (Table 6), this reveals that pozzolanic materials continue their strength development at a later day as long as there is favorable amount of temperature and moisture.

3.3.3. Post Hoc Test. Post hoc tests were further conducted for additional exploration of whether the differences among those means are significantly different within each level or not. Tukey's HSD test is used, as it is one of the popular post hoc test methods [53]. The post hoc test result of RHA replacement is illustrated in Table 7.

Based on the Tukey's HSD test, we can conclude that there is a statistically significant difference between $0 \%$ (OPC) and RHA 5\%, 10\%, and 20\% which has $\alpha$ value of $0.016,0.034$, and 0.002 , respectively, which all are less than 0.05 . However, RHA $15 \%$ has $\alpha$ value of 0.983 and this number is greater than 0.05 . Thus, there is no statistically significant difference between 0\% (OPC) and RHA 15\%.

\section{Conclusion}

From the study, it is concluded that the Ethiopian rice husk burnt at $550^{\circ} \mathrm{C}$ for 6 hours yields a good pozzolanic property for use as a supplementary cementitious material in concrete. The RHA used in the study also conforms to the chemical analysis requirements of class $\mathrm{N}$ pozzolan specified in ASTM C618. The laboratory test results reveal that the compressive strength of concretes made with RHA replacement of $5 \%$ to $20 \%$ significantly increases with an increase in age. However, as prior researchers argued, the workability of the trial mixes slightly decreases as the percentage of RHA increases. In this regard, the decrease in workability can be improved by adding a proper dosage of superplasticizing admixture. The statistical analysis results show that RHA replacements and age of concrete cubes significantly affect concrete compressive strength at $95 \%$ confidence interval and the cost analysis also shows that using RHA can save up to $10 \%$ of the total cost of concrete with $5 \%$ to $20 \%$ cement replacement levels.

Previously, multiple researchers in different regions tried to show the effect of using RHA as a supplementary cementitious material in concrete by replacing it in 5\% to $30 \%$ of ordinary Portland cement (OPC). However, there are still a dearth of studies that investigate the effect of using RHA with different cement types like Portland pozzolanic cement (PPC) with admixture and without admixture. Although previous studies tried to compare the test results using twodimensional graphs, there are limited studies that justified RHA use in concrete through a statistical approach. Thus, in addition to the analysis of various test results, this study also conducted a statistical analysis to investigate the validity of laboratory test results. Consequently, as the production process of RHA does not require a huge technology and finance, environmental and economic benefits can be 
exploited easily by using it especially in developing countries like Ethiopia, where the expansion of rice production capacity is one of the government's changing policies as an alternative food self-sufficiency. Future studies could focus on examining the Ethiopian RHA for high strength and high-performance concretes and evaluate the pozzolanic activities of the Ethiopian RHA using XRD analysis.

\section{Data Availability}

The data underlying the results presented in this study are available within the manuscript.

\section{Conflicts of Interest}

The authors declare that there are no conflicts of interest.

\section{References}

[1] H. Chao-Lung, B. L. Anh-Tuan, C. Chun-Tsun, and C. ChunTsun, "Effect of rice husk ash on the strength and durability characteristics of concrete," Construction and Building Materials, vol. 25, no. 9, pp. 3768-3772, 2011.

[2] B. Chatveera and P. Lertwattanaruk, "Durability of conventional concretes containing black rice husk ash," Journal of Environmental Management, vol. 92, no. 1, pp. 59-66, 2011.

[3] W. Xu, "Effect of rice husk ash fineness on porosity and hydration reaction of blended cement paste," Construction and Building Materials, vol. 89, pp. 90-101, 2015.

[4] M. Jamil, M. N. Khan, M. R. Karim, A. B. A. Kaish, and M. M. Zain, "Physical and chemical contributions of Rice Husk Ash on the properties of mortar," Construction and Building Materials, vol. 128, pp. 185-198, 2016.

[5] S. H. Sathawane, V. S. Vairagade, and K. S. Kene, "Combine effect of rice husk ash and fly ash on concrete by $30 \%$ cement replacement," Procedia Engineering, vol. 51, pp. 35-44, 2013.

[6] B. Mistry, "Properties and industrial applications of rice husk," International Journal of Engineering Science, vol. 2677, no. 10, pp. 86-90, 2016.

[7] S. Mann, "Achieving Sustainability By Partial Replacement Of Cement With Rice Husk Ash," International Journal of Engineering Research and Applications (IJERA), vol. 8, no. 10, pp. 9-13, 2018.

[8] L. Hu, Z. He, and S. Zhang, "Sustainable use of rice husk ash in cement-based materials: environmental evaluation and performance improvement," Journal of Cleaner Production, vol. 264, Article ID 121744, 2020.

[9] R. Khan, "Reduction in environmental problems using ricehusk ash in concrete," Construction and Building Materials, vol. 30, pp. 360-365, 2012.

[10] S. K. Antiohos, V. G. Papadakis, and S. Tsimas, "Rice husk ash (RHA) effectiveness in cement and concrete as a function of reactive silica and fineness," Cement and Concrete Research, vol. 61, no. 62, pp. 20-27, 2014.

[11] R. S. Padhi, "Influence of incorporation of rice husk ash and coarse recycled concrete aggregates on properties of concrete," Construction and Building Materials, vol. 173, pp. 289-297, 2018.

[12] A. A. Raheem and B. D. Ikotun, "Incorporation of agricultural residues as partial substitution for cement in concrete and mortar - a review," Journal of Building Engineering, p. 101428, 2020.
[13] S. Belay and A. Woldesenbet, "Study of the potential of Ethiopian rice husk as a partial replacement of cement," PROCEEDINGS Construction Research Congress, pp. 310-320, 2016.

[14] M. Belay, Assessment of Conditions of Contract Problems in Ethiopian Construction Industry, AAU Institutional Repository, Bahir Dar, 2017.

[15] D. G. Mengistu and G. Mahesh, "Challenges in developing the Ethiopian construction industry," African Journal of Science, Technology, Innovation and Development, vol. 12, no. 4, pp. 1-12, 2019.

[16] E. G. Sinesilassie, S. Z. S. Tabish, and K. N. Jha, "Critical factors affecting cost performance: a case of Ethiopian public construction projects," International Journal of Construction Management, vol. 18, no. 2, pp. 108-119, 2018.

[17] M. Dabai, "Studies on the effect of rice husk ash as cement admixture," Nigerian Journal of Basic and Applied Sciences, vol. 17, no. 2, pp. 252-256, 2010.

[18] R. S. Deotale, S. H. Sathawane, and A. R. Narde, "Effect of partial replacement of cement by fly ash, rice husk ash with using steel fiber in concrete," International Journal of Scientific Engineering and Research, vol. 3, no. 6, pp. 1-9, 2012.

[19] S. D. Nagrale, H. Hajare, and P. R. Modak, "Utilization of rice husk ash," International Journal of Engineering Research in Africa, vol. 2, no. 4, pp. 1-5, 2012.

[20] G. Akeke and M. Ephraim, "Structural properties of rice husk ash concrete," International Journal of Advances in Engineering Sciences and Applied Mathematics, vol. 3, no. 2, Article ID 8269, 2013.

[21] S. I. Khassaf, A. T. Jasim, and F. K. Mahdi, "Investigation the properties of concrete containing rice husk ash to reduction the seepage in canals," International Journal of Scientific \& Technology Research, vol. 3, no. 4, pp. 348-354, 2014.

[22] M. S. Kulkarni, P. G. Mirgal, P. P. Bodhale, and S. N. Tande, "Effect of rice husk ash on properties of concrete," Journal of Civil Engineering and Environmental Technology, vol. 1, no. 1, pp. 26-29, 2014.

[23] A. N. Givi, S. Abdul Rashid, F. N. Abdul Aziz, and M. a. Mohd Salleh, "Contribution of rice husk ash to the properties of mortar and concrete: a review," Journal of American Science, vol. 6, no. 3, pp. 157-165, 2010.

[24] D. A. Opeyemi and O. O. Makinde, "The suitability of partial replacement of cement with rice husk ash and bone powder in concrete structures," International Journal of Emerging Technology and Advanced Engineering, vol. 2, no. 9, pp. 261-265, 2012.

[25] J. Rajput, R. K. Yadav, and R. Chandak, "The effect of rice husk ash used as supplementary cementing material on strength of mortar," International Journal of Engineering Research in Africa, vol. 3, no. 3, pp. 133-136, 2013.

[26] I. O. Obilade, "Use of rice husk ash as partial replacement for cement in concrete," International Journal of Engineering and Applied Sciences, vol. 5, no. 4, pp. 11-16, 2014.

[27] P. Raikwar and V. Tare, "Study of concrete properties using rice husk ash and marble powder," International Journal of Emerging Technology and Advanced Engineering, vol. 4, no. 8, pp. 680-688, 2014.

[28] S. Ramesh, S. Kavitha, and R. H. Ash, "Experimental study on the behaviour of cement concrete with rice husk ash (rha)," International Journal of Engineering Science and Innovative Technology (IJESIT), vol. 3, no. 6, pp. 101-107, 2014.

[29] G. Abood-Habeeb and H. Bin-Mahmud, "Study on properties of rice husk ash and its use as cement replacement material," Materials Research, vol. 13, no. 2, pp. 185-190, 2010. 
[30] R. S. Bie, X. F. Song, Q. Q. Liu, X. Y. Ji, and P. Chen, "Studies on effects of burning conditions and rice husk ash (RHA) blending amount on the mechanical behavior of cement," Cement and Concrete Composites, vol. 55, pp. 162-168, 2015.

[31] M. Nehdi, J. Duquette, and A. El Damatty, "Performance of rice husk ash produced using a new technology as a mineral admixture in concrete," Cement and Concrete Research, vol. 33, no. 8, pp. 1203-1210, 2003.

[32] P. Chindaprasirt and S. Rukzon, "Strength, porosity and corrosion resistance of ternary blend Portland cement, rice husk ash and fly ash mortar," Construction and Building Materials, vol. 22, no. 8, pp. 1601-1606, 2008.

[33] A. P. Gursel, H. Maryman, and C. Ostertag, "A life-cycle approach to environmental, mechanical, and durability properties of "green" concrete mixes with rice husk ash," Journal of Cleaner Production, vol. 112, pp. 823-836, 2016.

[34] R. M. Ferraro and A. Nanni, "Effect of off-white rice husk ash on strength, porosity, conductivity and corrosion resistance of white concrete," Construction and Building Materials, vol. 31, pp. 220-225, 2012.

[35] V. T. A. Van, C. Rößler, D. D Bui, and H. M Ludwig, "Mesoporous structure and pozzolanic reactivity of rice husk ash in cementitious system," Construction and Building Materials, vol. 43, pp. 208-216, 2013.

[36] D. Chopra, R. Siddique, and Kunal, "Strength, permeability and microstructure of self-compacting concrete containing rice husk ash," Biosystems Engineering, vol. 130, pp. 72-80, 2015.

[37] J. Prasara-A and S. H. Gheewala, "Sustainable utilization of rice husk ash from power plants: a review," Journal of Cleaner Production, vol. 167, pp. 1020-1028, 2017.

[38] P. Jongpradist, W. Homtragoon, R. Sukkarak, W. Kongkitkul, and P. Jamsawang, "Efficiency of rice husk ash as cementitious material in high-strength cement-admixed clay," Advances in Civil Engineering, vol. 2018, Article ID 8346319, 11 pages, 2018.

[39] M. Amin and B. A. Abdelsalam, "Efficiency of rice husk ash and fly ash as reactivity materials in sustainable concrete," Sustainable Environment Research, vol. 1, no. 1, pp. 1-10, 2019.

[40] C. Astm, Standard Specification for Coal Fly Ash and Raw or Calcined Natural Pozzolan for UseAnnual Book of ASTM Standards, PA, USA, 2010.

[41] Astm, Standard Specification for Concrete Aggregates, Annual Book of ASTM Standards, West Conshohocken, PA, USA, 2010 .

[42] D. Sensale, "Strength development of concrete with rice-husk ash," Cement and Concrete Composites, vol. 28, pp. 158-160, 2006.

[43] A. Naji, S. A. Rashid, F. N. A. Aziz, and M. A. M. Salleh, "Assessment of the effects of rice husk ash particle size on strength, water permeability and workability of binary blended concrete," Construction and Building Materials, vol. 24, no. 11, pp. 2145-2150, 2010.

[44] M. F. M. Zain, M. N. Islam, F. Mahmud, and M. Jamil, "Production of rice husk ash for use in concrete as a supplementary cementitious material," Construction and Building Materials, vol. 25, no. 2, pp. 798-805, 2011.

[45] R. Pode, "Potential applications of rice husk ash waste from rice husk biomass power plant," Renewable and Sustainable Energy Reviews, vol. 53, pp. 1468-1485, 2016.

[46] S. Kosmatka, B. Kerkhoff, and W. C. Panarese, "Design and control of concrete mixtures. Fourteenth," International Journal of Mathematics and Mathematical Sciences.
Fourteenth. Skokie: Portland Cement Association, vol. 2003, Article ID 471490, 8 pages, 2003.

[47] S. Ross, Introduction to Probability and Statistics for Engineers and Scientists, Elsevier Academic Press, Cambridge, MA, USA, 3rd edition, 2004.

[48] A. B. Yeh, "Fundamentals of Probability and Statistics for Engineers," Technometrics, 2005.

[49] R. Walpole, R. Myers, and S. Myers, 'Probability \& Statistics for Engineers \& Scientists - Instructor's Solution Manual', Pearson, New York, NY, USA, 1998.

[50] A. Hayter, Probability and Statistics for Engineers and Scientists, University of Denver, Denver, Colorado, 4th edition, 2012.

[51] Y. C. Yong and N. E. Mustaffa, "Critical success factors for Malaysian construction projects: an empirical assessment," Construction Management \& Economics, vol. 31, no. 9, pp. 959-978, 2013.

[52] S. Belay and A. Woldesenbet, "Study of the potential of Ethiopian rice husks as a partial replacement of cement," in Proceedings of the Construction Research Congress 2016: Old and New Construction Technologies Converge in Historic San Juan - Proceedings of the 2016 Construction Research Congress, May 2016.

[53] B. A. Akinyemi, A. Elijah, A. Oluwasegun, D. T. Akpenpuun, and O. Glory, "The use of red earth, lateritic soils and quarry dust as an alternative building material in sandcrete block," Scientific African, vol. 7, 2020. 